\title{
Entrepreneurial Intention of Accountancy, Business and Management (ABM) Students in Nueva Ecija, Philippines
}

\author{
Kim Edward S. Santos, мBA \\ Wesleyan University-Philippines, Philippines \\ kimnyte@gmail.com
}

\begin{abstract}
The Philippines began a senior high school ( $K$ 12) curriculum in 2016 with the purpose of developing entrepreneurial students who are holistically developed, equipped with 21st-century skills, and prepared for the future. This study assessed the Accountancy, Business and Management (ABM) students' entrepreneurial intentions, its influencing factors, motivators, and obstacles. The quantitative-descriptive research technique was utilized in this study. This study surveyed total of 89 senior high school students (comprising of 37 Grade 11 students and 52 Grade 12 students) of Accountancy, Business and Management (ABM) Strand from private schools in Nueva Ecija. This study assessed the ABM students' entrepreneurial intentions, its influencing factors, motivators, and obstacles. It was then concluded that (1) rather than working as an employee in a corporation, student - respondents want to start their own business and be their own boss; and the course they attended had an effect on their self-efficacy in making professional selections; (2) they looked up to their family for advice on how to become an entrepreneur one day, which could be because their family has a business experience; (3) motivation factors show that student - respondent do not dwell on focusing personal gaining of status they will achieve then they become entrepreneurs as they are motivated to give support for potential entrepreneurs, use their creative talent, and take risk; and (4) to establish a business, one needs have sufficient savings to employ as capital, as well as entrepreneurial skills. It is also crucial to have the right mindset while starting a business because there are dangers and uncertainties to consider.
\end{abstract}

Keywords- Entrepreneur, Accountancy, Business, Management, Entrepreneurial.

\section{INTRODUCTION}

The Philippines began a senior high school (K-12) curriculum in 2016 with the purpose of developing entrepreneurial students who are holistically developed, equipped with 21 st-century skills, and prepared for the future. Entrepreneurship is a critical aspect in economic and social development, as it is a primary generator of job creation and national prosperity (Van Praag \& Versloot, 2007).

To foster an entrepreneurial culture, educational systems must be structured to highlight and value entrepreneurship (do Paço et al., 2011). There is research suggesting that educational programs can influence entrepreneurial attributes favorably (Athayde, 2009) and that many entrepreneurship programs and curricula are capable of increasing awareness of entrepreneurship as a career choice and encouraging favorable attitudes toward entrepreneurship (Anderson and Jack, 2008).

Entrepreneurial intention is influenced by a variety of factors; however the primary personality traits such as selfefficacy, risk-taking, initiative for business start-up, a favorable attitude toward business, behavioral control, the need for achievement, and an internal locus of control can be developed through education (Remeikiene et al., 2013). Education programs should place an emphasis on favorably impacting students' attitudes toward entrepreneurship and building their self-efficacy for starting a new business (Mariano et al., 2012).

Educational programs have been deemed extremely promising in terms of increasing the supply of potential entrepreneurs (i.e., increasing public awareness and interest in this career option) and emerging entrepreneurs (making more people try to start a new venture) (Liñán et al., 2011).

Entrepreneurship programs should not be limited to entrepreneurship classes, but should incorporate classroom and market experience, as well as student and entrepreneurial networks (Mueller, 2011). Also, students should be motivated by government officials, nongovernmental organizations, and financial institutions to provide financial help, marketing infrastructure, and other infrastructure such as information technology, as well as advice or counsel on entrepreneurship (Achchuthan \& Kandaiya, 2013). 
In light of these results, there is a need to assess senior high school students' entrepreneurial intent, particularly those enrolled in the Accountancy, Business, and Management (ABM) strand.

\section{OBJECTIVES OF THE STUDY}

This study assessed the Accountancy, Business and Management (ABM) students' entrepreneurial intentions, its influencing factors, motivators, and obstacles.

\section{METHODOLOGY}

The quantitative-descriptive research technique was utilized in this study, which comprises the description, recording, analysis, and interpretation of a real-world condition. When gathering knowledge on the current state of circumstances, the descriptive technique is acceptable (Creswell, 2014). This study employed convenience sampling. This study surveyed a total of 89 senior high school students (comprising of 37 Grade 11 students and 52 Grade 12 students) ofAccountancy, Business and Management (ABM) Strand from private schools in Nueva Ecija. The questionnaire was adopted from Samuel et al. (2013).

\section{RESULTS AND DISCUSSIONS}

Table 1. Entrepreneurial Intention

\begin{tabular}{|c|c|c|}
\hline Statement & Mean & Verbal Interpretation \\
\hline 1. My professional goal is to become an entrepreneur & 3.87 & Agree \\
\hline 2. I prefer to be an entrepreneur rather than to be an employee in a company & 4.38 & Strongly Agree \\
\hline 3. I am prepared to do anything to be an entrepreneur & 3.80 & Agree \\
\hline 4. I'll put every effort to start and run my own business & 4.41 & Strongly Agree \\
\hline 5. I have thought seriously to start my own business after completing my study & 3.79 & Agree \\
\hline 6. I have a strong intention to start a business someday & 3.58 & Agree \\
\hline 7. I'm determined to create a firm in the future & 3.60 & Agree \\
\hline 8. I want to be my own boss & 4.34 & Strongly Agree \\
\hline 9. I will start my business in the next five years & 3.92 & Agree \\
\hline Average Weighted Mean & 3.97 & Agree \\
\hline
\end{tabular}

\section{Legend Verbal Interpretation (VI)}

4.20 - 5.00 Strongly Agree (SA)

3.40 - 4.19 Agree (A)

2.60 - 3.39 Neutral (N)

1.80 - 2.59 Disagree (D)

1.00 - 1.79 Strongly Disagree (SD)

Table 1 shows the entrepreneurial intention of ABM students. The student - respondents got an average weighted mean of 3.97 that has a verbal interpretation of "Agree". They strongly agreed on Statement 8 "I want to be my own boss." (Mean = 4.34), Statement 4 "I'll put every effort to start and run my own business." (Mean = 4.41), and Statement 2 "I prefer to be an entrepreneur rather than to be an employee in a company" (Mean = 4.38). The results indicate that student - respondents' entrepreneurial intention is to putting their own business and becoming the boss rather than serving as an employee in a company. This means that the course where the student - respondents enrolled in their course gives an impact to their self-efficacy in making career decisions. The analysis validates that prior exposure to entrepreneurship education has a beneficial effect on students' views toward a career in entrepreneurship as well as their perceived behavioral control or entrepreneurial self-efficacy, according to Ajzen's (1991) model. 
Table 2. Variables Influencing Entrepreneurial Intention

\begin{tabular}{|cl|c|c|}
\hline \multicolumn{2}{|c|}{ Variables } & Mean & Verbal Interpretation \\
\hline 1. & Families & 4.22 & Strongly Agree \\
\hline 2. & Academics/Lecturers & 3.97 & Agree \\
\hline 3. & Career Advisors & 3.86 & Agree \\
\hline 4. & Friends & 4.15 & Agree \\
\hline 5. & Entrepreneurs & 3.85 & Agree \\
\hline 6. & Business People & 3.98 & Agree \\
\hline & Average Weighted Mean & 4.01 & Agree \\
\hline
\end{tabular}

\section{Legend Verbal Interpretation (VI)}
4.20 - $5.00 \quad$ Strongly Agree (SA)
3.40 - 4.19 Agree (A)
2.60 - 3.39 Neutral $(\mathrm{N})$
1.80 - 2.59 Disagree (D)
1.00 - 1.79 Strongly Disagree (SD)

Table 2 shows the variables influencing entrepreneurial intention that has an average weighted mean of 4.01 that has a verbal interpretation of "Agree". Student respondents strongly agreed that their family (Mean $=$ 4.22) was the most influencing factor in their entrepreneurial intention. Other top factors are friends (Mean $=4.15)$, business people $($ Mean $=3.98)$, and academics / lectures $($ Mean $=3.97)$. The result indicates that student - respondents looked up to their family to become an entrepreneur someday. This may be because their family has already a background in business. The analysis contradicts the claims of Samuel, Ernest, and Awuah, (2013) that academics/lecturers, career advisors, and / or business people are most influential in the decision making in relation to starting own business.

Table 3. Motivators of Entrepreneurial Intentions

\begin{tabular}{|r|r|r|}
\hline \multicolumn{1}{|c|}{ Items } & Percentage & Rank \\
\hline 1. To provide employment & 50.77 & 20 \\
\hline 2. To provide job security & 70.20 & 7 \\
\hline 3. Opportunities in the market & 74.75 & 6 \\
\hline 4. $\quad$ Earn a reasonable living & 56.94 & 16 \\
\hline 5. To take advantage of my creative talent & 81.49 & 3 \\
\hline 6. Support for potential entrepreneurs & 82.43 & 1 \\
\hline 7. For my own satisfaction and growth & 63.03 & 12 \\
\hline 8. To be my own boss & 67.76 & 11 \\
\hline 9. To realize my dream & 60.96 & 13 \\
\hline 10. For my personal freedom & 68.45 & 10 \\
\hline 11. To challenge myself & 50.95 & 19 \\
\hline 12. Good economic environment & 55.84 & 17 \\
\hline 13. I enjoy taking risk & 82.26 & 2 \\
\hline 14. To invest personal savings & 70.12 & 8 \\
\hline 15. To use the skills learned in the university & 80.92 & 5 \\
\hline
\end{tabular}




\begin{tabular}{|l|r|r|}
\hline 16. Entrepreneurial family culture & 59.37 & 14 \\
\hline 17. Increase my prestige and status & 55.72 & 18 \\
\hline 18. Follow the example of someone that I admire & 70.00 & 9 \\
\hline 19. To maintain my family & 81.21 & 4 \\
\hline 20. Enjoy myself & 57.69 & 15 \\
\hline
\end{tabular}

\section{* Multiple Response}

Table 3 shows the motivation factors of the ABM students of their entrepreneurial intentions. Among the following, the top three motivation factors are "Support for potential entrepreneurs" (82.43\%), "I enjoy taking risk" (82.26\%), and "To take advantage of my creative talent" (81.49\%). This results show that personal motivation factors emerged the top priority of the student - respondents. On the other hand, the lowest three motivation factors are "To provide employment" (50.77\%), "To challenge myself" (50.95\%), and "Increase my prestige and status" (55.72\%). These factors show that student - respondent do not dwell on focusing personal gaining of status they will achieve then they become entrepreneurs. The analysis supports the claim of Samuel, Ernest, and Awuah, (2013) that motivators are to take advantage of creative talent, to earn reasonable living, and to provide employment.

Table 4. Obstacles to Entrepreneurial Intention

\begin{tabular}{|c|c|c|}
\hline Items & Percentage & Rank \\
\hline 1. Lack of Savings & 83.14 & 1 \\
\hline 2. Difficulty in obtaining bank finance & 66.42 & 7 \\
\hline 3. Lack of assets for collateral & 50.87 & 16 \\
\hline 4. Lack of business skills (financial, marketing) & 80.19 & 3 \\
\hline 5. Lack of information about how to start a business & 52.39 & 14 \\
\hline 6. Lack of business experience & 56.41 & 12 \\
\hline 7. Lack of information about any government agency that can assist in funding my business & 66.34 & 8 \\
\hline 8. High cost of business registration & 72.53 & 6 \\
\hline 9. Fear of starting business due to risk involve & 51.09 & 15 \\
\hline 10. Future uncertainty & 82.64 & 2 \\
\hline 11. Fear of business failure & 76.45 & 5 \\
\hline 12. Weak economic environment & 65.04 & 9 \\
\hline 13. Lack of support from family or friend & 54.35 & 13 \\
\hline 14. Difficulty in convincing others that is a good idea to carry on & 64.38 & 10 \\
\hline 15. No one to turn to for help & 57.83 & 11 \\
\hline 16. Difficult to find right partners & 78.47 & 4 \\
\hline
\end{tabular}

\footnotetext{
* Multiple Response
}

Table 4 shows the obstacles of the ABM students of their entrepreneurial intentions. Among the following, the top three obstacles are "Lack of savings" (83.14\%), "Future uncertainty" (82.64\%), and "Lack of business skills (financial, marketing)" (81.49\%). On the other hand, the least among the obstacles are "Lack of assets for collateral" (50.87\%), and "Fear of starting business due to risk involve" (51.09\%), and "Lack of information about how to start a business" $(52.39 \%)$. The results indicate that to start a business, one must have savings to be used as capital and he /she must have the business skills. Proper mindset is also important to start a business because risks involve and uncertainties may come. This confirms the findings of Olufunso (2010) in South Africa in which the 
biggest obstacle was lack of savings and difficulties in obtaining bank finance.

\section{CONCLUSIONS AND RECOMMENDATIONS}

This study assessed the ABM students' entrepreneurial intentions, its influencing factors, motivators, and obstacles. It was then concluded that (1) rather than working as an employee in a corporation, student - respondents want to start their own business and be their own boss; and the course they attended had an effect on their self-efficacy in making professional selections; (2) they looked up to their family for advice on how to become an entrepreneur one day, which could be because their family has a business experience; (3) motivation factors show that student - respondent do not dwell on focusing personal gaining of status they will achieve then they become entrepreneurs as they are motivated to give support for potential entrepreneurs, use their creative talent, and take risk; and (4) to establish a business, one needs have sufficient savings to employ as capital, as well as entrepreneurial skills. It is also crucial to have the right mindset while starting a business because there are dangers and uncertainties to consider.

The researcher recommends that $\mathrm{ABM}$ students should be given proper education and training to deepen understanding in starting business and to develop their entrepreneurial skills such as creativity, risk taking, communication, and invention while they are in the academe. The schools build linkages to government and private business sectors where students can find a place for work immersion. Family support is also important and students should be open to their family regarding their career decisions and plans.

\section{REFERENCES}

[1] Achchuthan, S., \& Kandaiya, S. (2013). Entrepreneurial intention among undergraduates: Review of literature. Sivarajah, K., \& Achchuthan, S.(2013). Entrepreneurial Intention among Undergraduates: Review of Literature. European Journal of Business and Management, 5(5), 172-186.

[2] Ajzen, I. (1991) Theory of planned behavior. Organizational Behavior and Human Decision Processes 50, 179-211.

[3] Anderson, A. R., \& Jack, S. L. (2008). Role typologies for enterprising education: the professional artisan?. Journal of small business and enterprise development.
[4] Athayde, R. (2009). Measuring enterprise potential in young people. Entrepreneurship theory and practice, 33(2), 481-500.

[5] Creswell, J. W. (2014). A concise introduction to mixed methods research. SAGE publications.

[6] do Paço, A. M. F., Ferreira, J. M., Raposo, M., Rodrigues, R. G., \& Dinis, A. (2011). Behaviours and entrepreneurial intention: Empirical findings about secondary students. Journal of International Entrepreneurship, 9(1), 20-38.

[7] Liñán, F., Rodríguez-Cohard, J. C., \& RuedaCantuche, J. M. (2011). Factors affecting entrepreneurial intention levels: a role for education. International entrepreneurship and management Journal, 7(2), 195-218.

[8] Moriano, J. A., Gorgievski, M., Laguna, M., Stephan, U., \& Zarafshani, K. (2012). A cross-cultural approach to understanding entrepreneurial intention. Journal of career development, 39(2), 162185.

[9] Mueller, S. (2011). Increasing entrepreneurial intention: effective entrepreneurship course characteristics. International Journal of Entrepreneurship and Small Business, 13(1), 55-74.

[10] Olufunso, F.O. (2010). Graduate Entrepreneurial Intentions in South Africa: Motivations and Obstacles. International Journal of Business and Management, $5(9), 87-98$.

[11]Remeikiene, R., Startiene, G., \& Dumciuviene, D. (2013, June). Explaining entrepreneurial intention of university students: The role of entrepreneurial education. In International conference (pp. 299-307).

[12] Samuel, Y. A., Ernest, K., \& Awuah, J. B. (2013). An assessment of entrepreneurship intention among Sunyani Polytechnic Marketing students. International Review of management and Marketing, 3(1), 37.

[13] Van Praag, C. M., \& Versloot, P. H. (2007). What is the value of entrepreneurship? A review of recent research. Small business economics, 29(4), 351-382. 